\title{
Wetlands in Ethiopia: Lessons From 20 years of Research, Policy and Practice
}

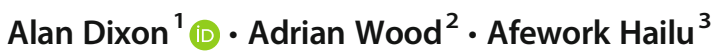 \\ Received: 29 July 2020 / Accepted: 2 October 2020 / Published online: 10 February 2021 \\ (C) The Author(s) 2021
}

\begin{abstract}
Throughout sub-Saharan Africa wetlands provide ecosystem services that are critical to the development needs of many people. Local wetland use, however, is often at odds with broader national policy goals in which narratives of conservation and protection dominate, hence a recurring challenge is how to reconcile these tensions through the development of policies and field practice that deliver sustainable development. In this paper we examine the extent to which this challenge has been achieved in Ethiopia, charting the changes in wetlands policy and discourse over the last twenty years while reviewing the contribution of the multidisciplinary Ethiopian Wetlands Research Programme (EWRP) (1997-2000). Our analysis suggests that despite EWRP having a significant legacy in developing national interest in wetlands among research, government and non-governmental organisations, its more holistic social-ecological interpretation of wetland management remains neglected within a policy arena dominated by specific sectoral interests and little recognition of the needs of local people. In exploring the impacts at the local level, recent investigations with communities in Ilu Aba Bora Zone highlight adjustments in wetland use that famers attribute to environmental, economic and social change, but which also evidence the adaptive nature of wetland-based livelihoods.
\end{abstract}

Keywords Ethiopia $\cdot$ Wetland management $\cdot$ Policy $\cdot$ Conservation $\cdot$ Sustainable development

\section{Wetlands and Sustainable Development}

Over the last 40 years the narrative of 'wetlands under threat' has dominated the global discourse on wetlands, driving subsequent wetland policy, planning and management, which has for the most part remained focused on delivering conservation outcomes (Maltby 1986; Dugan 1990; Farrier and Tucker 2000; Barker 2009). There is of course a rationale for this; Davidson (2014) suggests that between $54-57 \%$ of the world's wetlands have been lost since 1900, and this has commonly been attributed to the rapid increase in agricultural drainage, irrigation schemes, dam construction and conversion for residential or industrial use that go hand in hand with

Alan Dixon

a.dixon@worc.ac.uk

1 School of Science and the Environment, University of Worcester, Worcester, UK

2 University of Huddersfield, Huddersfield, UK

3 Ethio-Wetlands and Natural Resources Association, Addis Ababa, Ethiopia economic growth-centred interpretations of 'development' (Maltby 1986; Adams 1992; Hughes 1996; Schuyt 2005; Mafabi 2005; Wood et al. 2013). Despite the notable successes of the Ramsar Secretariat and large international NGOs in mitigating and reducing wetland loss though global awareness-raising campaigns and legislative action, these pressures arguably remain more acute throughout the developing world in areas where people's livelihoods and very survival depend on wetland use.

Nowhere is this more evident than in Africa, where wetlands constitute approximately 16 per cent of the continent's total area and have long been recognised as playing a critical role in supporting the livelihoods of people in marginal areas through their provision of a range of ecosystem services (Trapnell and Clothier 1937; Turner 1986; Hollis 1990; Scoones 1991; Adams 1993; Woodhouse et al. 2000; MA 2005; Wood et al. 2013). In northern Nigeria, for example, seasonally flooded depressions known as 'fadamas' have supported the livelihoods of hundreds of thousands of smallholder farmers for generations (Tarhule and Woo 1997; DanAzumi 2010; Tanko 2013), while similarly across central and southern Africa 'dambos' continue to support water provision, fishing, grazing, seasonal agriculture and wild plant 
collection (Whitlow 1983; Bell et al. 1987; Roberts 1988; Wood and Thawe 2013). However, despite a plethora of academic work drawing attention to this, and evidence that locallevel wetland use throughout Africa has often occurred in a sustainable manner in the past, the significance of smaller wetlands has remained under-recognised in the Eurocentric global wetlands discourse for many years. While serious consideration of the links between livelihoods and wetlands began to emerge during the 1980s and 1990s in terms of 'traditional' non-destructive uses (Marchand and Udo 1989; Davis 1994; Roggeri 1998, Gawler 2002), it was the 2000s before a more explicit focus on wetlands and poverty reduction took place (Silvius et al. 2000; Wetlands International 2005; Mundy 2009; McCartney et al. 2010; Wood et al. 2013) due in many respects to the influence of the Millennium Development Goals and thereafter the Millennium Ecosystem Assessment (MA) (MA 2005).

In emphasising the inter-relationships between ecosystem services and development outcomes, and especially the tradeoffs that often occur between these, the MA has been particularly influential in reframing wetlands as social-ecological systems. This has shifted ideas about wetland management beyond simplistic neo-Malthusian interpretations of peopleenvironment relationships and inevitable environmental destruction, to systemic approaches that emphasise the dynamic and adaptive inter-relationships between ecological and social systems at different scales. In recent years social-ecological theory has presented various approaches (see Berkes et al. 2003; Ostrom 2009; Binder et al. 2013; Virapongse et al. 2016; Colding and Barthel 2019) for analysing environmentsociety interactions which draw upon widespread empirical evidence of the importance of human agency; people continuously adapt, organize and negotiate their relationship with resources and the environment, and have an inherent interest in sustaining the social, economic and environmental benefits from this relationship. Sustainable social-ecological systems are characteristically resilient and able to buffer and absorb shocks and pressures whilst continuing to function, whereas less resilient systems are more sensitive to external pressures, vulnerable to environmental degradation and ultimately unsustainable (Adger 2000; Folke et al. 2002; Berkes et al. 2003). A critical prerequisite to resilience is adaptive capacity, which in ecological systems is linked to biodiversity and the heterogeneity of landscapes, while in social systems it is enhanced through knowledge diversity, social networks and institutions (Berkes et al. 2003). In translating this into policy and practice, much attention has focussed on 'adaptive comanagement' as a transdisciplinary approach that seeks to work with resource users, particularly at the community level, to identify and enhance institutional structures, knowledge sharing networks and appropriate monitoring systems in order to build adaptive capacity (Olsson et al. 2004; Armitage et al. 2009).
Within this context the key challenge for Africa's critically important smaller wetlands becomes arguably less about how to conserve and protect them from people, and more about how to ensure their ecosystem services and livelihood benefits can be sustained for the future in the face of numerous shocks and pressures. Rapid population growth, socio-economic change, and the prevalence of government policies that uncouple economic growth and poverty reduction from environmental concerns present such challenges to which local wetland users must adapt. Indeed, with wetlands in Africa already becoming a 'new agricultural frontier' (Dixon and Wood 2003; Maconachie et al. 2009) wetland use has itself emerged as an adaptive strategy to land shortages, land degradation and a decline in the quality and quantity of rain-fed harvests in upland farmland. Moreover, as the impacts of climate change become more acute, the ecosystem services derived from small wetlands are likely to constitute an ever-increasing component of people's livelihoods (Wood et al. 2013; Langan et al. 2018; Pettinotti et al. 2018). In this paper we reflect on the extent to which these challenges have been addressed in Ethiopia, where wetlands are ubiquitous landforms and where, like the rest of Africa, many local communities depend on them for food and livelihood security. In particular, we explore the legacy of the Ethiopian Wetlands Research Programme (EWRP) (1997-2000) as the first initiative to place a more nuanced, people-focussed view of wetlands on the national agenda, and discuss its influence on wetland discourse, policy and practice in Ethiopia over the last twenty years. We return to field practice in the final part of the paper, drawing on recent field investigations undertaken with some communities with whom EWRP worked. Here we consider how wetland use and management has changed at the local level and how users have responded to wider social-ecological and economic change linked to Ethiopia's development. We conclude by identifying lessons for practice and policy from our exploration at different levels over the last 20 years.

\section{Wetlands in Ethiopia}

The abundance and distribution of wetlands throughout Ethiopia remains unclear not least because of inconsistencies in the ways they are identified or delineated. Recent work (Abebe and Geheb 2003; Bezabih and Mosissa 2017; EWNHS 2018) tends to either draw on reports by wildlife conservation organisations (Hillman 1993; Abunje 2003) or those of government departments which have focussed on Ethiopia's large lake-wetland complexes or river valleys, hence identification of what constitutes a wetland often reflects the agenda of those undertaking the survey. As noted elsewhere, this is often to the neglect of smaller but no less important wetlands (Wood et al. 2013). Nonetheless, estimates suggest wetlands cover $1-2 \%$ of the country's total 
land area, and typically occur as highland riverine swamps across the central plateau, Rift Valley lakes, and lowland floodplains such as those found in the Baro-Akobo system (Abunje 2003; Wood et al. 2016; EWNHS 2018). Despite Ethiopia not ratifying the Ramsar Convention on Wetlands of International Importance, many wetlands are internationally recognised for their biodiversity; Bird Life International (2002) suggest that 31 out of 68 designated Important Bird Areas (IBAs) in Ethiopia also fulfil the criteria for Ramsar designation. The Berga wetland near Addis Ababa, for example, is an internationally recognised protected habitat for the critically endangered White-winged Flufftail (Ash and Atkins 2009).

Ethiopia's wetlands have long been used by local populations to derive livelihood benefits. Fishing is an important livelihood strategy in the Rift Valley lakes and Lake Tana, while in riverine floodplains and small headwater swamps, agricultural drainage and cultivation, as well as livestock grazing, are widely practised (McCann 1995; Tesfaye and Wolff 2014). The agricultural use of wetlands, known as 'bone' in some areas, typically involves drainage or at the very least the utilisation of residual moisture during dry periods of the year to cultivate crops that coincide with the food-insecure period caused by the end of the upland maize supply. Wetlands have also traditionally provided grazing resources for cattle, medicinal plants, craft-making and construction material, and water for domestic consumption. Evidence suggests that the agricultural conversion of wetlands expanded significantly throughout the 20th century as an adaptation to declining upland yields and population pressure, but also as a direct and indirect result of the application of government policies on forced resettlement, upland coffee expansion, the commercialisation of agriculture and food security targets in some parts of the country (Dixon 2003a). Consequently, from the 1990s onwards concerns were raised about the rate of agricultural development, its potential impact on wetlands and livelihoods in the long-term, and the capacity of local wetland management systems to adapt to these changes.

\section{The Ethiopian Wetlands Research Programme (EWRP)}

These concerns provided the rationale for EWRP, a three-year multidisciplinary EU-funded project developed in 1997 to investigate the dynamics of wetland use in Ethiopia's western highlands. The programme involved collaboration between universities, NGOs, government institutions and local wetland stakeholders, with implementation initially targeting three weredas (districts) in Ilu Aba Bora (formerly Illubabor) Zone. While EWRP's overall (and arguably ambitious) goal was to '...achieve the sustainable management of wetlands throughout the area' (Wood and Dixon 2000, p4), the programme first sought to understand in detail the environmental and socio-economic processes and impacts of wetland utilisation, before seeking to develop and test sustainable wetland management practices in the field, building on local knowledge. Towards the end of the programme, activities centred on disseminating the findings both vertically in terms of informing wetland policy stakeholders within Ethiopia, and laterally through facilitating a range of farmer-to-farmer extension initiatives. Much has been written elsewhere about EWRP's findings (see for example, Wood and Dixon 2000; Dixon 2003a, Dixon and Wood 2003) but it is perhaps useful here to revisit the key themes and issues emerging in order to reappraise their wider significance and influence since the programme's completion in 2000.

Estimates in 1998 suggested that wetlands comprised $1.4 \%$ of Ilu Aba Bora Zone's total land area $\left(227 \mathrm{~km}^{2}\right.$ out of $\left.16,636 \mathrm{~km}^{2}\right)$ and approximately $21 \%$ of this $\left(48 \mathrm{~km}^{2}\right)$ was under cultivation by around 15,300 farmers with maize accounting for $92 \%$ of the wetland crop. This area was less than originally expected, and according to farmers represented a decline from $27 \%$ in 1990 (Wood and Dixon 2000). Prior to this, however, the pattern emerging was one of a steady increase in wetland agricultural use since the 1950s, with various peaks and troughs occurring in response to inward migration, prevailing food security conditions, and market opportunities. For poorer farmers, wetlands were regarded as safety nets during times of need, while for the more speculative asset-rich farmer, they provided opportunities for income diversification (Mulugeta 2004). Moreover, each wereda (and indeed each community studied) was found to respond differently; wetland drainage and cultivation was a function of each socialecological context in which the distribution and availability of other livelihood assets played an important role. An increase in the number of cattle, for example, meant that wetland cultivation ceased in some areas in order to provide grazing resources. Similarly, where farmers experienced a shortage of wetland sedge for roofing, wetland cultivation declined (Dixon 2003a).

This is indicative of what was perhaps one of the most critical aspects of EWRPs research findings; that wetland users possessed detailed, dynamic and adaptive local knowledge of wetlands in terms of environmental change and the impacts of their own interventions on the environment. Through a process of in-field experimentation, wetland users had developed a range of practices and strategies adapted to their specific environment, and which utilised soil and vegetation indicators of sustainability (Dixon 2003a). Consequently, evidence for the Malthusian hypothesis of environmental collapse that initiated EWRP's activities in the first place, failed to materialise. Rather, the research revealed that while environmental degradation characterised by declining water table elevation, ecological change and soil compaction does occur as a result of drainage and cultivation, this can be short-term and reversible. Moreover, farmers understand this process and adopt spatial 
and temporal rotational management strategies in their wetlands to balance environmental security with livelihood benefits. Critically, these strategies were found to be facilitated and supported by the presence of local institutions at the community level, which developed a set of commonly agreed rules of engagement for wetlands (Dixon and Wood 2007), much akin to many other sustainable common property resource systems (Ostrom 1990; Agrawal 2001; Pretty and Ward 2001). Wetlands represent a challenging environment for farmers, and only with coordination, reciprocity, and a shared vision of sustainability, can the benefits be maintained in the long-term.

Once this detailed picture of wetlands emerged, and following the identification of wetlands where 'good practice' was observed, EWRP began a programme of extension and dissemination of its findings and the local management lessons farmers had developed. This was delivered via workshops and short training courses for farmers and wetland stakeholders at the wereda and zonal government levels, a national workshop, radio broadcasts, farmer-to-farmer extension events, and the development of Oromiffa, Amharic and English extension booklets and briefing papers. In most cases, the 'take home' lessons from the programme included the following:

- Wetlands can make an important contribution to livelihoods, food security and poverty reduction without undermining the natural resource base that supports these contributions. This is facilitated by wetland management strategies and practices that balance different uses;

- Local people possess detailed environmental knowledge of the wetlands they use, and this shapes their interactions with them. While its dynamic and adaptive nature promotes sustainable development, some farmers lack the assets that enable them to apply their knowledge;

- Working with local institutional arrangements is critical for delivering sustainable outcomes (or through actions that build capacity for institutional arrangements);

- Not all wetlands and their users are the same; socioeconomic differentiation (and social-ecological uniqueness) influences the dynamics of wetland use in different places;

- Wetland policy-makers (conservation, water resources and agricultural development) need to consider these contexts; planners need to talk to wetland users and interventions should be participatory and sensitive to the local socio-ecological setting.

Some twenty years on these may come across as rather trite statements, particularly in the context of the aforementioned contemporary debates surrounding the importance of adaptive co-management, social-ecological resilience and adaptation, common pool resource management, and the ways in which the Ramsar Secretariat and NGOs have subsequently celebrated the role of local people in wetland management (IWMI 2014; Oviedo and Kenza Ali 2018; Ramsar 2018). At the time, however, EWRP's work was embraced as the first systematic, sustained and multi-disciplinary investigation of wetlands in Ethiopia, not least by IUCN's Wetlands and Water Resources Programme which sought to capitalise on EWRP's momentum by co-ordinating an international conference on wetlands of Ethiopia, the publication of which (Abebe and Geheb 2003) became a seminal reference work for subsequent wetland studies. Moreover, in a country dominated by a focus on achieving food security through agricultural development, the significance of EWRP's work lay in the suggestion that a win-win outcome for food security and the environment could be achieved (at least as long as EWRP's recommendations were considered). It also raised some important issues and challenges for national level policy-makers in terms of how to reconcile competing sectoral interests in wetlands towards this potentially achievable win-win goal.

\section{EWRP's Institutional Legacy?}

A number of institutional developments followed the completion of EWRP in 2000, the most important of which was the establishment by its national project coordinator of Ethiopia's first wetlands-focussed NGO, the Ethio-Wetlands and Natural Resources Association (EWNRA) with the goal of 'ensuring sustainable wetland and ecosystem functions, services and attributes for the wellbeing of local communities and wider socioeconomic and environmental objectives' (EWNRA 2011, p 19). Originally envisaged as a means of continuing the dissemination and extension of EWRP's important messages within the country, EWNRA subsequently developed an extensive portfolio of community-focused participatory projects concerned with empowering communities in addressing environmental and development challenges. To date, EWNRA has worked on over 50 projects involving more than 500,000 beneficiaries and including stakeholders from conservation, development, agriculture and health sectors, as well as local and international NGOs and government departments. It now manages an annual budget of just under $\$ 3 \mathrm{~m}$.

EWNRA has been informed and supported by another legacy of EWRP; Wetland Action (WA), a not-for-profit organisation was created by EWRP researchers in 2000 as a knowledge-sharing platform for the dissemination of EWRPs ideas and to facilitate collaborative action research among wetland practitioners, NGOs and academics in Africa and beyond. Post-EWRP, WA maintained close links with Ethiopia and used its growing network to connect EWNRA to international organisations, thereby building further institutional capacity. WA also continued to collaborate with EWNRA on various research projects that addressed 
questions surrounding community-based wetland management that emerged from the original research (Dixon 2005; Dixon and Wood 2007).

Since 2000, EWNRA's wetland-related projects and activities have made specific contributions to the thinking about wetlands in Ethiopia. In its early years EWNRA continued to work closely with communities and local government in Ilu Aba Bora, Western Wellega and Jimma zones, most notably in the former where it addressed the wetland management challenges raised by the Ministry of Agriculture's 'Wetland Task Force'. Between 1999 and 2003, this policy sought to increase food production from wetlands in line with national food security targets by pressurising communities to doublecrop their wetlands. When one community contested this on the grounds that it would degrade their wetland, EWNRA acted as an independent expert and negotiator in the argument, which the community eventually won. Meanwhile, EWNRA's Wichi project (PHE 2012) developed EWRP's work by focusing on the important social-ecological linkages between wetlands and their catchments, offsetting the potentially negative impacts of wetland agricultural intensification by embedding and institutionalising improvements to uplandbased farming and livelihoods. At the time, this 'Functional Landscape Approach' (FLA) was positioned as a progressive shift in wetland management thinking within Ethiopia in terms of demonstrating the interdependence of conservation and development, upland and wetland, social and environmental processes, and the need for policy and practice to consider these. The Wichi project itself facilitated food and water security for over 2700 households in the area, while also building local wetland management institutional capacity among 148 community members and training government development workers (PHE 2012). EWNRA staff reported a high demand for similar training from local farmers and government workers in neighbouring areas.

EWNRA further established its position as the leading national NGO engaging in wetland practice and policy through its work around Lake Tana in Amhara region that promoted sustainable wetland use through catchment environmental and development interventions, and in Kefa zone, land use planning of two wetlands and their catchments was undertaken for the regional government with support from FAO. Beyond its field operations, EWNRA has also developed a strong advocacy presence within Ethiopia. It continues to develop and disseminate wetland extension material to NGOs and government, and has shared its experiences through national events such as the annual World Wetlands Day. Five regional and national workshops held between 2001 and 2014 (EWNRA $2005,2008,2009,2014$ ) have showcased the contribution of wetlands to food security and both economic and social development, while acknowledging the importance of sustaining the environmental processes that underpin these benefits. These have explored the role of wetlands in addressing climate change (EWNRA 2009), reviewed the linkage between wetlands and watershed management (EWNRA 2014). Within these meetings there have been repeated calls to develop a national wetland policy, and EWNRA has lobbied vociferously for Ethiopia's accession to the Ramsar Convention, supporting the country's delegations at Ramsar COPs since the 2002 COP 8 in Spain. One might expect EWNRA, therefore, to have had a significant impact on the evolution of wetland management practice and policy in Ethiopia during the last 20 years, not least since its implementation and advocacy activities have aligned with a gradual shift in the global wetlands discourse away from 'fortress conservation' (Brockington 2002) to greater acknowledgement of the role of local people in sustainable wetland management, a focus on catchment-wetland linkages, ecosystem service restoration and of course the need for cross-sectoral engagement.

\section{Evolving Wetlands Policy}

Before turning to wetlands policy it is important to consider the wider context of social, economic, political and environmental change in Ethiopia. Indeed, the example above of the 'wetlands task force' illustrates well the ways in which wetland use and management has occurred at a multi-sectoral policy interface populated by a range of stakeholders with concerns ranging from agricultural productivity and food security, to health and water resource planning. This is itself nested within a national context of population growth, globalisation and environmental change. While a discussion of wider development trends in Ethiopia is beyond the scope of this paper, it is clear that Ethiopia has been one of Africa's economic development success stories during the last twenty years, experiencing rapid acceleration in GNI (annual growth rates averaging $9.9 \%$ between 2007 and 2018) significant and sustained levels of FDI and ODA, and a reduction in extreme poverty from $51 \%$ in 2000 to $27 \%$ in 2019 . This has been despite a $70 \%$ increase in population over the same period (World Bank 2020). The last twenty years have also witnessed significant investments in water and energy security typified by a series of controversial large dam projects (Abbink 2012), as well as transformation across the agricultural sector (Bachewe et al. 2017). However, whilst these macroeconomic indicators are impressive, they nonetheless mask regional differences and the continued multidimensional challenges of poverty across the country. Economic development has gone hand in hand with further agricultural expansion, land degradation and deforestation (Keenan et al. 2015; Getahun et al. 2013; Betru et al. 2019; Young et al. 2020), and concerns are growing about how these will exacerbate the impacts of climate change on the poorest and more vulnerable sections of society. Government policy, therefore, has the unenviable task 
of meeting economic growth and development targets, while also reducing environmental degradation, and as we now discuss, these polarised tensions continue to frame Ethiopia's approach to wetlands.

Despite increasing interest in wetlands there has to date been no national specific co-ordinated policy on wetlands in Ethiopia. Instead, wetlands have occupied a cross-sectoral position in the policies of numerous government agencies which have often been contradictory (Amsalu and Addisu 2014). For example, the only mention of wetlands in the Ministry of Water Resources' (later the Ministry of Water, Irrigation and Energy) Ethiopian Water Sector Strategy in 2002 related to the need to, "Reclaim existing wetlands, and prevent the formation of the new ones..." with a goal to "carry out appropriate drainage works on all wetlands." (MoWR 2001, p4). This is despite an overarching commitment to water resources conservation and watershed management. Similarly, the Ministry of Finance and Economic Development's 'Rural Development Policy and Strategies' (MoFED 2003) considered irrigation, water conservation, river diversion and dams as important means of developing food security. Meanwhile, although the agricultural use of wetlands has a long history, the Ministry of Agriculture and Rural Development avoids any explicit mention of wetlands in its 'Agricultural Sector Policy and Investment Framework 2010-2020' where again irrigation, soil and water conservation, and watershed management are emphasised (MoARD 2010a). Of particular note is the way this ministry's Sustainable Land Management Programme, focused in the degraded areas, especially in the northern highlands, has taken a watershed management approach, but to date has paid little attention to the downslope impacts of improved water infiltration which have led to small / micro wetlands being regenerated and becoming locally important for vegetable production (Schmidt and Tadesse 2019). Clearly while the benefits that wetlands provide underpin development strategies, the connections between wetlands and these benefits are never explicitly recognised in policy. This is acutely evident in the way rice production has been heavily promoted over the last two decades, especially in the wetland areas of Gambella Region and Fogera in the Lake Tana Basin where there has been little recognition of upstreamdownstream linkages (MoARD 2010b; Alemu et al. 2018). This continued official lack of recognition of the dependency of agriculture and development on wetlands arguably creates a dangerous policy gap, rendering wetlands open to abuse particularly at decentralised levels of government.

Among those stakeholders concerned with environmental protection and conservation wetlands have received more attention. The Environmental Protection Authority (EPA) established in 1995 developed the work of the National Conservation Strategy of Ethiopia and enshrined in policy the need to rehabilitate and protect wetlands in the interest of conserving water resources, and where necessary undertake environmental impact assessment of any development (EPA 1997). More recently, the Climate Resilient Green Economy policy launched in 2012 (FDRE 2011) positions wetland management (in its broadest sense) as critical in mitigating greenhouse gas emissions. In 2017, EPA's policies and remit were subsumed into the newly created Environment, Forest and Climate Change Commission (EFCCC), yet to date the commission has focused more on forest management, particularly carbon payments through REDD+. Notably in its most recent 'State and Outlook of the Environment' report it concedes that wetlands, “...tend to be lightly mentioned in the environment and water related polices and strategies. There are no worth mentioning initiatives to protect wetlands." (EFCCC 2017, p97).

With respect to a national wetland policy, this has long been discussed in Ethiopia since Abebe and Geheb (2003). This was followed up in 2008 in EWNRA's national wetland workshop where a concluding resolution suggested "Creating a National Commitment for Wetland Policy and Strategy in Ethiopia" (EWNRA 2008). While a draft national law was also discussed at EWNRA's 2009 workshop on 'Wetlands and Climate Change' (EWNRA 2009), the momentum on wetland policy development declined until the build up to the Ramsar COP in Dubai in 2018 where the NGO Wetlands International and the Norwegian government committed to supporting Ethiopia's Ramsar accession and development of a national wetland policy. Since the COP, and as a result of technical assistance from Wetlands International, both through advisers in the EFCC Commission and the establishment of a country office and field projects, a draft wetland policy has been developed and progress made towards an application to join Ramsar. In both these processes EWNRA has also played a major consultative role. The draft proclamation for Wetland Protection and Sustainable Management focuses on maintaining the ecological character of Ethiopia's wetlands and establishing protected wetlands. Throughout there is reference to sustainable development as being the goal for wetland management, but this is only defined in terms of a 'continued ability to meet the needs and aspirations of present and future generations'. Some attention is given to present use, including agriculture, and the need for understanding traditional knowledge of wetland management as well as catchment linkages to ensure the sustainability of wetland use. However, there remains no explicit recognition of the livelihood or food security needs of wetland farmers, and here once again there is arguably a disconnect with different institutional priorities and the different situations in the field (although the draft is currently undergoing further review).

With regards joining the Ramsar Convention, there has been a long history of concern by Ethiopian authorities about the restrictions this could impose on the country. As a result, a technical study exploring the impact of Ramsar Convention ratification in Ethiopia was commissioned after the Ramsar COP in 2018 and has been reviewed by stakeholders both at 
a one-day meeting in July 2019 and through follow up consultations (Damtie and Arsano 2018). The aim was to advise the government and those concerned with Ethiopia's Ramsar accession about the potential restrictions on further development of water resources and on the development of wetlands for agricultural production. The former relates to energy developments such as those recently made on the Omo and Blue Nile rivers, while the latter likely refers to lakeside farming in the Rift Valley and Lakes Tana and Turkana. The study concluded that the benefits of joining the Convention exceed the restrictions / costs, and stressed that the Ramsar Convention no longer focused only on conservation but now recognises sustainable development. The only immediate conflict was noted to be with the 2001 Ethiopian Water Sector Strategy (MoWR 2001).

In finalising the wetland policy there are also the different interests of the ten regional states in this federal country to be considered. In some regions, wetlands are important for seasonal food security (Feyissa et al. 2019), for commercial crop production (Takele 2010) and for irrigation and livestock grazing in the Rift Valley and the river valleys (Bondestam 1974). These will require specific recognition to address concerns of the communities and the regional states. This is possible, as the federal system allows regions to interpret the federal proclamations as they make their own laws and so address local needs, but will require sufficient flexibility in the over-arching federal law, something yet to be explored with respect to wetland policy. Beyond any regional finetuning of policy, there are also practicalities to be considered. In the first instance major challenges will exist for wetland policy implementation to be coordinated with other agencies, especially those responsible for agriculture and water. At the wereda level, the EFCC is poorly resourced compared to other ministries, especially MoARD which has three development agents living and working with communities in each kebele. At field level, such as the EWRP sites, there is a need to ensure that no conflicting advice is provided and that the dangers of top-down extension are avoided, recognising the rights of the farmers to use wetlands in their own adaptive way, alongside the need to balance ecosystem services to ensure sustainability (Wood and van Halsema 2008).

Notwithstanding these continuing challenges, the progress toward legal initiatives shows that despite a long absence of policy dialogue on wetlands, the voices of those in EWNRA and in government agencies like EPA and EFCCC are becoming more mainstream. However, even despite the promises of the draft wetland proclamation, policy in Ethiopia remains somewhat polarised and arguably continues to fall short of the desperately needed shift towards a more systemic and inter-sectoral recognition of the social-ecological value of wetlands to environment and society. With the notable exception of Uganda, few countries in sub-Saharan Africa have made significant progress in this regard, yet with such a rich legacy of research and practice across different agroecological environments, there is huge potential for Ethiopia to emerge as a regional leader in integrated wetlands policy and management.

\section{The Local Perspective}

We now turn to the question of what, if anything, has been the impact of these broader policy changes and debates on local wetland users and researchers. Certainly, one discernible legacy of EWRP and EWNRA's work over the last 20 years has been the proliferation of studies within Ethiopia that have explored issues of wetland degradation, sustainability, and livelihoods, and in some cases these have drawn heavily on EWRP's research approach (albeit in different geographical contexts) (Mulatu et al. 2013; Haji 2019; Yilma 2019). In mirroring the trends in policy discussed above, these have gone some way in highlighting the spatial and temporal experiences of people and wetland management from different parts of the country post-2000, yet most studies have similarly positioned continuing wetland use in almost identical narratives of environmental degradation and the need for conservation, and in doing so fail to critically evaluate their in-situ experiences in the context of EWRPs key findings and recommendations as highlighted earlier (Gebreselassie et al. 2014; Amsalu and Addisu 2014; Tulu and Desta 2015; Jigar et al. 2016; Moges et al. 2018; Giweta and Worku 2018; Tafa 2018; Wondie 2018; Haji 2019). Few evidence any significant engagement or consultation with wetland-users themselves.

There are exceptions, however, and some have explored in a more sensitive manner the social-ecological dynamics of wetland use. For instance, Mulatu et al. (2015) in their study of the socio-economic impacts of wetland cultivation among communities in South-Bench, report a continued high dependency of local people on wetlands for agriculture (driven by upland food shortages) yet an overall decline in livelihood benefits due to the associated loss of natural vegetation. Here, ambiguous land tenure issues are identified as a barrier to sustainable use. In the Cheffa wetland in the Awash Basin, Bekele (2011) similarly attributes emerging conflicts between wetland users to a wetland institutional vacuum at the local and government level; again, population pressure and a growing dependency on wetland resources among the wider population is further exacerbating these tensions. In communitybased work in Dale wereda, SNNPR, Babu and Teferi (2015) meanwhile highlight the emergence of a classic 'tragedy of the commons' scenario characterised by overgrazing in wetlands along the Gidabo River system, as well as drainage and the encroachment of settlement. Here, and as noted by Babu (2015) in Bule Hora Wereda in Oromia Region, population pressure has also been linked to catchment deforestation, and the planting of both eucalyptus and khat (Catha edulis) in 
wetlands. Notwithstanding some methodological issues, it is difficult to avoid drawing the conclusion from these and the many other small-scale empirical studies that 'things are getting worse' for wetlands and wetland-users in their different situations throughout Ethiopia, and there is scant evidence of any innovative practice and adaptive management among wetland users that EWRP research identified and EWNRA disseminated. While this no doubt reflects the agenda and positionality of these studies (and, if anything, the enduring and permeating presence of the polarising conservationdevelopment arguments) it is still arguably indicative of a lack of progress in studies to integrate a more social-ecological analysis of wetlands and contribute this to the national agenda.

In attempting to investigate further the situation for farmers, in 2017 we visited three wetland communities in Metu wereda, Ilu Aba Bora Zone. Two of these - Tulube Mendido and Bake Chora Kemisse - were study sites with whom EWRP had collaborated some 20 years earlier during their programme of participatory research and capacitybuilding activities, whilst the third - Wichi - was the site of EWNRA's catchment management activities between 2005 and 2008. The aim here was to identify what changes had occurred in wetland management and people's livelihoods since the end of these projects, and in particular to ascertain any influence the projects had achieved. At each site the format for discussion was a group meeting of between 6 and 10 farmers in which a timeline was used as a participatory focusing exercise. Whilst these discussions were by no means comprehensive, they do provide a snapshot of some trends and issues that have emerged.

\section{Tulube Wetland}

Tulube wetland $\left(8^{\circ} 19^{\prime} 55.75^{\prime \prime} \mathrm{N} 35^{\circ} 33^{\prime} 15.30^{\prime \prime} \mathrm{E}\right)$ is a small headwater wetland of approximately 6 hectares that is typical of those throughout the western highlands in terms of its Cyperus latifolius climax vegetation (known locally as cheffe) and a seasonal flooding regime (Dixon 2003a). Agricultural cultivation of this wetland reportedly dates back to the later years of the Haile Selassie era (1960-1974), although it was abandoned around 1983 in response to declining crop productivity but also a shortage of oxen for draught power. During EWRP's work in 1998 the wetland was classed as 'regenerating', with human activity in the wetland limited to the collection of cheffe, medicinal plants and water. Post2000, however, the most significant change in wetland use has been the start of wetland cultivation once again in 20032004 following the intervention of the government's 'wetland task force'. Monocropping of maize, which was common before 1983, has also been superseded by the double cropping of tef (Eragrostis tef), sugar cane, potato, pepper, tomato, cabbage and onion, alongside maize. While farmers were positive about this 'enforcement', they also acknowledged a trade-off with the reduced supply of cheffe, so that now upland vetiver grass provides thatching materials. The traditional ' $A b b a$ Laga' wetland management institution which previously coordinated wetland use, was also noted to have declined with government development agents replacing them as the de facto decision-maker. Moreover, farmers report an overall decline in the yield from wetland cultivation compared to the Haile Selassie era:

"We used to use the produce from wetlands for three months of the year; now this has declined to one or a half a month... we are replacing it with nothing - we are food insecure for the other months".

In offering an explanation for this observed decline, farmers cite soil degradation linked to more prolonged cultivation, declining fertility, catchment deforestation, and the persistence of erratic rainfall, especially during the last decade. The increase in eucalyptus planting in the catchment was also linked to downslope water shortages, yet interestingly, farmers link their own native tree-planting actions in the catchment as having a positive, if short-term, impact on rainfall and the availability of moisture and, critically, this is something they attribute to their past experiences with EWRP and EWNRA:

"... we learned not to do harmful things in the catchment, and in the wetland we became more aware of degradation. We learned that we can restore the wetland and catchment through certain practices. That is what we have to do now".

While this indicates that farmer understand well the causes of wetland degradation and possess the knowledge of how to address this, when it comes to food security alone from wetlands there was unanimous agreement that crop-raiding by wild animals constitutes the biggest threat:

"The biggest problem is wild animals. With land degradation we can control this through soil and water management ... we are doing that... but we are not able to control or reduce the impacts of the wild animal population. This has increased over time. Even the animals are taking products from our homes. This is the worst problem".

As discussed elsewhere (see Quirin and Dixon 2012) the issue of crop raiding in wetland agriculture is inextricably linked to the demise of Abba Laga. This has been attributed to poor support from external government institutions, but also a concurrent move towards individual rather than 
collective action characterised by different farmers growing different crops and using their wetland plots in different ways.

\section{Bake Chora Wetland}

Bake Chora Kemisse ( $\left.8^{\circ} 12^{\prime} 41.37^{\prime \prime N} 35^{\circ} 36^{\prime} 7.48^{\prime \prime} \mathrm{E}\right)$ is similarly a small headwater wetland (3 hectares) which, according to farmers in 1998, had been drained and cultivated repeatedly since the period of Menelik II (1889-1913). In 1998 maize and tef were grown, while small areas at the head of the wetland were reserved for cheffe for use as thatch (Dixon 2003a). Whilst presented as an example of sustainable management by Wood et al. (2000) farmers at the time did report a slight decline in crop yields over time, and during our 2017 discussions suggested this had continued until cultivation of the whole wetland ceased in 2007. However, rather than declining soil fertility being responsible for this abandonment:

"We stopped ploughing because we were hampered by different wild animals... boye [pig], tota [vervet monkey], zinjero [baboon] and jart [porcupine] ... The animals damage the crops and the population is increasing over time".

While farmers here attributed the wild animal problem primarily to the government's prohibition of culling, they also recognise that it has been exacerbated through their own actions in driving forward unprecedented levels of afforestation in the catchment - both eucalyptus and native 'coffee forest', with the latter estimated to having doubled in area since 1997. As farmers have benefited economically from the sale of eucalyptus, coffee and more recently khat, the cash from this has seemingly replaced the need for the labour-intensive wetland agriculture. Another sign of market influences in 2017 was the use of the wetland for cattle fattening for the nearby urban market in Metu, while cheffe production for local use continued. Unlike Tulube, and for reasons not entirely clear, Bake Chora escaped the attention of the 2003 Wetlands Task Force. Since wetland agriculture has been abandoned at Bake Chora it was also difficult to pinpoint any legacies of the EWRP work, although it is possible that this abandonment may have in part been influenced by their (arguably erroneous) interpretation of what was discussed some years earlier:

"We learned that ploughing in the wetland is not advisable... and that it can affect the climate"

It is worth noting here that Bake Chora was the subject of a short evaluation study in 2002 (see Dixon 2003b) during which farmers recalled the adaptations made during a time when they continued to be reliant on wetland agriculture:
"We learned through training how to drain and cultivate the wetland - how to make the ditches the right depth. Before they [EWRP] came the water was low but after we were able to manage the water in the drains better." "Before 5 years the soil in that area down there was like stone. When we learnt that we should keep the cattle out and remove the plant waste the soil has gone smooth and we can manage the water in it better. Keeping the cattle out of the wetland has also increased the fertility of the soil. We have also kept the area of cheffe at the top of the wetland."

However, the cattle are now back in the wetland for fattening and the cultivation has stopped in part due to changing returns to farmers for their labour on different activities. Urban growth in the neighbouring town of Metu has also fuelled the demand for khat, coffee, beef and timber, and hence this has led to a re-evaluation of the use of this wetland by farmers.

\section{Wichi Wetland}

Wichi wetland $\left(8^{\circ} 18^{\prime} 5.32^{\prime \prime} \mathrm{N} 35^{\circ} 31^{\prime} 46.36 " \mathrm{E}\right)$ was the target area of EWNRA's Wichi Integrated Watershed Programme (2005-2008) which sought to reduce wetland degradation through enhancing upland productivity with livelihood diversification measures and building institutional capacity within the community to support this (PHE 2012; Dixon et al. 2013). Despite farmers elaborating upon the successes of this project during our field discussions, they acknowledged that some benefits had not been sustained post-project. This was attributed to several inter-related issues emerging from a shift in annual rainfall patterns that has affected upland production. This, along with population pressure, subsequently led to an increase in wetland cultivation and grazing among the wider community in this vicinity, i.e. those who were not included in EWNRA's project. Linked to this is the observation that the wetland institutional arrangements, the Abba Laga, were no longer enforcing the rules of wetland use established during the project:

"We had governing rules for Abba Laga about what you should and shouldn't do in wetlands, so there was very little ploughing... but after the project there was no coordination. Because of climate change cattle are now grazing in the wetlands and people from other kebeles are ploughing... We are conserving but others are not doing the same. No one is supporting the rules."

Again, this echoes the experiences outlined in Dixon and Wood (2007) where many failing Abba Laga arrangements were attributed by farmers to a lack of support from external organisations such as the wereda administration that, somewhat paradoxically, were seen as key in legitimising the 
authority of traditional associations. Overall though, the picture of wetland management emerging from Wichi is one of an inability of the project participants to adapt to the changes taking place, alongside a reliance on external assistance.

\section{Issues Emerging From the Field}

Together, these snapshots of more recent wetland management experiences in Ilu Aba Bora Zone illustrate well how socio-economic, institutional and environmental change continue to shape the wetland management experiences for farmers and the status of wetlands themselves. This mirrors recent experience elsewhere in Ethiopia and Africa more broadly in terms of the impacts of climate change, land degradation, population pressure, socio-economic change, market penetration and a lack of coherent wetland policies and institutional arrangements (Sakane et al. 2012; Leauthaud et al. 2013; Rodenburg et al. 2014; Ayeni et al. 2019; Munishi and Jewitt 2019). These were all seen by farmers in these three sites as interrelated challenges with which they had to contend. While these pressures were common to all, however, our findings also draw attention to the unique social-ecological differences between these communities in terms of their responses to these pressures. As noted earlier, the sustainable use of wetlands rests on users' capacity to continually adapt to these, which requires the availability of livelihood assets, the knowledge gained through experience, social networks, coordination between users, and a supporting socio-political environment (Ostrom 1990; Agrawal 2001; Berkes et al. 2003), so to what extent were these evident?

First, in relation to livelihood assets, farmers acknowledged how their past project experiences have enhanced their assets in different ways as evidenced, for example, through their knowledge of destructive and restorative practices and the inter-connectedness of people and environment, wetland and catchment. Yet despite this, the direct contribution of wetlands to livelihoods in each of the sites has declined in recent years. While on one hand this could point to an inability to adapt to changes such as the demands of the wetlands task force, the growing wild pest problem or the encroachment of people from other areas, on the other it could be argued that farmers have adapted to their changing social-ecological setting by developing livelihood opportunities beyond wetlands, e.g. through eucalyptus, coffee and khat. This has reduced the immediate agricultural pressure on wetlands, allowed opportunities for regeneration, and enhanced non-agricultural ecosystem services, but it has also encouraged their use for cattle fattening. This supports evidence from elsewhere (e.g. Jogo and Hassan 2010) that points to farmers making rational spatial trade-offs in wetland ecosystem services as an adaptive strategy to shocks and pressures. It further raises an issue of whether for many in the region the function of wetlands is to provide a steppingstone to other livelihood activities rather than a long-term career.

Secondly, in relation to knowledge, social networks and coordination that are also important pre-requisites to adaptive capacity, again there is little doubt that farmers have acquired new knowledge about their wetlands and continue to learn from their experiences, and this has been aided by the networking provided by their participation in EWNRA and EWRP projects as well as the local institutions associated with wetland use. Critically, even though the influence of these institutions has declined (a trend normally associated with unsustainable resource use (Ostrom 1990; Agrawal 2001; Pretty and Ward 2001)) farmers have adapted to this by shifting the focus of their livelihoods, as discussed above. Finally, it seems clear that the lack of a supporting socio-political environment in terms of local government recognition of wetlands and a sensitivity to the diversity of locally-adapted wetland management practices, knowledge and institutional arrangements, is an overarching issue for farmers that arguably threatens to undermine the sustainability of these social-ecological systems. Indeed, evident from our discussions with farmers was their sense of frustration that they knew how wetlands work and what the challenges were, that their EWRP and EWNRA experience had been invaluable in this regard, but that their voices were not being heard to command technical support from government development agents.

\section{Conclusions}

There is widespread evidence from our review that wetlands of all sizes continue to play a vital role in supporting the livelihoods of people throughout Ethiopia as they have done for generations. Through their provision of ecosystem services wetlands provide a basic safety net of food and water security for many of the poorest people, while for others they offer an opportunity to develop and diversify livelihood and incomegenerating opportunities. It is perhaps encouraging that 20 years after EWRP and EWNRA's original research and advocacy activities there is greater recognition of this importance across the country, as reflected in the growing number of local university research projects and the gradual evolution of government policy - in the environmental sector at least. However, despite EWNRA playing a significant role in promoting wetlands as multifunctional resources with multisectoral connections, hegemonic narratives and structures that present wetlands as being threatened by local people and inappropriate management have arguably frustrated the NGO's attempts to deliver truly transformational policy and practice. That is not to deny that wetlands are threatened by over-exploitation; indeed, we have seen that accelerated environmental and socio-economic change has and will render wetlands more vulnerable to degradation. Rather, our concern 
is that these narratives have continued to overlook the complex social-ecological dynamics of wetland environments and ignored the ways in which local people in many instances have been solely responsible for sustaining the range of wetland ecosystem services that are so universally lauded by managers and policymakers. At best this evidences a failure of EWRP and EWNRA to successfully communicate this message more widely during the past two decades; at worst it possibly represents a failure and rejection by some of decentralised policy and management, as well as the notion that local people have the potential to manage wetlands sustainably and should be supported in doing so if the promise of sustainable development is to be realised.

Yet, our most recent discussions with farmers in Ilu Aba Bora reaffirm how wetland use and management cannot be viewed in isolation from environmental and socio-economic processes in their catchments and beyond, and that the 'performance' of wetland utilisation inevitably changes over time as a livelihood adaptation to changing circumstances. While current use does not reflect EWRPs findings and recommendations from 20 years ago, there is little doubt that farmers retain the social and institutional memory of wetland use during that time, which itself is critical for adaptive capacity, resilience and sustainability in social-ecological systems (Berkes et al. 2003). Despite the gradual evolution of wetland policy and practice discussed above that has become more people-focussed, however, there has been little if any recognition among policymakers of enhanced communitylevel adaptive capacity as a pre-requisite to sustainable wetland management, or indeed much consideration of wetlands as social-ecological systems. Going forward, therefore, we would argue that this is key, and that in addition to developing guidelines for locally adapted wetland management, equal attention should be given to developing a cross-sectoral wetland policy environment that integrates flexibility, systems thinking, and the policy and institutional space that supports and enhances locallevel adaptive co-management of wetlands and NGOs that support this. As we write, it is encouraging that the draft of Ethiopia's first Wetlands Protection and Sustainable Management Proclamation has begun to integrate some of these ideas in a manner that will shape policy and practice for the next 20 years.

Acknowledgements The authors gratefully acknowledge the field assistance provided by Zelalem Adugna, EWNRA Project Co-ordinator, and the farmers of Bake Chora, Tulube and Wichi who participated in this work. We also thank two anonymous reviewers for their supportive and insightful feedback on an earlier draft of this paper.

Author Contributions Alan Dixon designed the research, collected field data and led the writing of the manuscript. Adrian Wood assisted field data collection and contributed to the writing of the manuscript. Afework Hailu contributed data and contributed to the writing of the manuscript.

Funding This research was funded by the University of Worcester's Research and Project Leave Scheme.
Data Availability Not applicable.

Code Availability Not applicable.

\section{Compliance with Ethical Standards}

Conflicts of Interest/Competing Interests The authors declare that they have no conflict of interest.

Ethics Approval Ethics approval was obtained in accordance with the University of Worcester Ethics Policy.

Consent to Participate Informed consent was obtained from all individual participants included in the study.

Consent for Publication Informed consent for publication of field data was obtained from all individual participants included in the study.

Open Access This article is licensed under a Creative Commons Attribution 4.0 International License, which permits use, sharing, adaptation, distribution and reproduction in any medium or format, as long as you give appropriate credit to the original author(s) and the source, provide a link to the Creative Commons licence, and indicate if changes were made. The images or other third party material in this article are included in the article's Creative Commons licence, unless indicated otherwise in a credit line to the material. If material is not included in the article's Creative Commons licence and your intended use is not permitted by statutory regulation or exceeds the permitted use, you will need to obtain permission directly from the copyright holder. To view a copy of this licence, visit http://creativecommons.org/licenses/by/4.0/.

\section{References}

Abbink J (2012) Dam controversies: contested governance and developmental discourse on the Ethiopian Omo River dam. Social Anthropology/Anthropologie Sociale 20:125-144

Abebe Y, Geheb K (2003) Wetlands of Ethiopia. IUCN, Nairobi

Abunje L (2003) The distribution and status of Ethiopian wetlands: an overview. In: Abebe Y, Geheb K (Eds) Wetlands of Ethiopia, Proceedings of a seminar on the resources and status of Ethiopia's wetlands. IUCN, Nairobi, pp 116

Adams WM (1992) Wasting the rain: rivers, people and planning in Africa. Earthscan, London

Adams WM (1993) Indigenous use of wetlands and sustainable development in West Africa. The Geographical Journal 159:209-218

Adger WN (2000) Social and ecological resilience: are they related? Progress in Human Geography 24:347-364

Agrawal A (2001) Common property institutions and sustainable governance of resources. World Dev 29:1649-1672

Alemu D, Tesfaye A, Assaye A, Addis D, Tadesse T, Thompson J (2018) A historical analysis of rice commercialisation in Ethiopia: the case of the Fogera plain. APRA Working Paper 18. Future Agricultures Consortium, Brighton. Available via: https://opendocs.ids.ac.uk/ opendocs/handle/20.500.12413/14283. Accessed 28 July 2020

Amsalu T, Addisu S (2014) A review of wetland conservation and management policy in Ethiopia. International Journal of Scientific and Research Publications 4:9 Available via: http://citeseerx.ist.psu.edu/ viewdoc/download?doi=10.1.1.654.2323\&rep=rep1\&type=pdf. Accessed 28 July 2020 
Armitage DR, Plummer R, Berkes F, Arthur RA, Charles AT, DavidsonHunt IJ, Diduck AP, Doubleday NC, Johnson DS, Marschke M, McConney P, Pinkerton EW, Wollenberg EK (2009) Adaptive comanagement for social-ecological complexity. Frontiersin Ecology and the Environment 7:95-102

Ash J, Atkins J (2009) Birds of Ethiopia and Eritrea: an atlas of distribution. Christopher Helm, London

Ayeni AO, Ogunsesan AA, Adekola OA (2019) Provisioning ecosystem services provided by the Hadejia Nguru Wetlands, Nigeria -Current status and future priorities. Scientific African 5:e00124

Babu A (2015) Assessment of challenges and opportunities of wetlands management in Bule Hora woreda, Borena Zone, Southern Ethiopia. Science Technology Arts Research Journal 4:99-111

Babu A, Teferi B (2015) Assessment of human induced threats to Warameda Wetland Dale woreda southern Ethiopia. International Journal of Fauna Biological Studies 2:25-33

Bachewe F, Berhane G, Minten B, Taffesse A (2017) Agricultural transformation in Africa? Assessing the evidence in Ethiopia. World Development 105:286-298

Barker T (2009) Introduction: sustainable wetlands in a global context. In: Maltby E, Barker T (eds) The wetlands handbook. WileyBlackwell, Chichester, pp 821-828

Bekele S (2011) Matching socioeconomic and ecological need in wetland management using systems approach: the case of Cheffa wetland in Ethiopia. Masters Dissertation, Swedish University of Agricultural Sciences, Uppsala. Available via https://stud.epsilon.slu.se/3299/4/ bekele_s_111002.pdf. Accessed 28 July 2020

Bell M, Faulkner R, Hotchkiss P, Lambert R, Roberts N, Windram A (1987) The use of dambos in rural development, with reference to Zimbabwe. Final report to ODA, Loughborough University and University of Zimbabwe

Berkes F, Colding J, Folke C (2003) Navigating social-ecological systems: building resilience for complexity and change. Cambridge University Press, Cambridge

Betru T, Tolera M, Sahle K, Kassa H (2019) Trends and drivers of land use/land cover change in western Ethiopia. Applied Geography 104: 83-93

Bezabih B, Mosissa T (2017) Review on distribution, importance, threats and consequences of wetland degradation in Ethiopia. International Journal of Water Resources Environmental Engineering 9:64-71

Binder CR, Hinkel J, Bots PWG, Pahl-Wostl C (2013) Comparison of frameworks for analyzing social-ecological Systems. Ecology and Society $18: 26$

Bird Life International (2002) Important bird areas and potential ramsar sites in Africa. Bird Life International, Cambridge. Available at https://www.birdlife.org/sites/default/files/attachments/AfricaIBAs-\%20 \%26-Ramsar-sites.pdf. Accessed 28 July 2020

Bondestam L (1974) People and capitalism in the north-eastern lowlands of Ethiopia. The Journal of Modern African Studies 12:423-439

Brockington D (2002) Fortress conservation: the preservation of the Mkomazi Game Reserve, Tanzania. James Currey, Oxford

Colding J, Barthel S (2019) Exploring the social-ecological systems discourse 20 years later. Ecology and Society 24:2

Damtie M, Arsano (2018) Validation workshop for the research report 'Exploring the Impact of the Ramsar Convention Accession in Ethiopia'. Environment, Forests and Climate Change Commission, Addis Ababa

Dan-Azumi J (2010) Agricultural sustainability of fadama farming systems in northern Nigeria: the case of Karshi and Baddegg'. International Journal of Agricultural Sustainability 8:319-330

Davidson N (2014) How much wetland has the world lost? Long-term and recent trends in global wetland area. Marine Freshwater Research 65:934-941

Davis TJ (1994) The Ramsar Convention manual: A fuide to the convention on wetlands of international importance especially as waterfowl habitat. Ramsar Convention Bureau, Gland
Dixon AB (2003a) Indigenous management of wetlands: experiences in Ethiopia. Ashgate, Aldershot

Dixon AB (2003b) The indigenous evaluation of wetlands research in Ethiopia. Development in Practice 13:394-398

Dixon AB (2005) Wetland sustainability and the evolution of indigenous knowledge in Ethiopia. The Geographical Journal 171:306-323

Dixon AB, Wood AP (2003) Wetland cultivation and hydrological management in East Africa: matching community and hydrological needs through sustainable wetland use. Natural Resources Forum $27: 117-129$

Dixon AB, Wood AP (2007) Local institutions for wetland management in Ethiopia: sustainability and state intervention. In: van Koppen B, Giordano M, Butterworth J (eds) Community -based water law and water resources management reform in developing countries, Comprehensive Assessment of Water Management in Agriculture Series 5. CABI International, Wallingford, pp 130-145

Dixon AB, Hailu A, Semu T (2013) Local institutions, social capital and sustainable wetland management: Experiences from western Ethiopia. In: Wood AP, Dixon AB, McCartney M (eds) Wetland management and sustainable livelihoods in Africa. Earthscan, London, pp 85-111

Dugan PJ (1990) Wetland conservation: a review of current issues and action. IUCN, Gland

EFCCC (2017) Ethiopia: State and outlook of the environment 2017. Environment, forest and climate change commission, Addis Ababa. Available via: https://www.efccc.gov.et/sectors/ environment/366-state-of-environment.html. Accessed 28 July 2020

EPA (1997) Environmental policy of Ethiopia. Environmental Protection Authority, Addis Ababa. Available via: https:/www.efccc.gov.et/ policies-laws/policies.html. Accessed 28 July 2020

EWNRA (2005) Proceedings of the second awareness creation workshop on wetlands in Amhara Region. Ethio-Wetlands and Natural Resources Association, Addis Ababa

EWNRA (2008) Proceedings of the national stakeholders' workshop on creating national commitment for wetland policy and strategy development in Ethiopia. Ethio-Wetlands and Natural Resources Association, Addis Ababa

EWNRA (2009) Proceeding of national advocacy workshop on wetlands and climate change. Ethio-Wetlands and Natural Resources Association, Addis Ababa

EWNRA (2011) 2011 Annual Report. Ethio-Wetlands and Natural Resources Association, Addis Ababa

EWNRA (2014) Impacts of integrated watershed and wetland management projects in Fogera Woreda, Amhara Region. Ethio-Wetlands and Natural Resources Association, Addis Ababa

EWNHS (2018) A first directory of Ethiopian wetlands: descriptions, ecosystem services, causes of degradation and recommendations for restoration and sustainability. Ethiopian Wildlife and Natural History Society, Addis Ababa

Farrier D, Tucker L (2000) Wise use of wetlands under the Ramsar Convention: a challenge for meaningful implementation of international law. Journal of Environmental Law 12:21-42

FDRE (2011) Ethiopia's climate-resilient green economy: green economy strategy. Federal Democratic Republic of Ethiopia, Addis Ababa. Available via: https://www.undp.org/content/dam/ethiopia/ docs/Ethiopia\%20CRGE.pdf. Accessed 28 July 2020

Feyissa ME, Cao J, Tolera H (2019) Integrated remote sensing-GIS analysis of urban wetland potential for crop farming: a case study of Nekemte district, western Ethiopia. Environmental Earth Sciences $78: 153$

Folke C, Carpenter C, Elmqvist L et al (2002) Resilience and Sustainable Development: Building Adaptive Capacity in a World of Transformations. Scientific Background Paper on Resilience for the process of The World Summit on Sustainable Development on 
behalf of The Environmental Advisory Council to the Swedish Government. Norsteds tryckeri AB, Stockholm

Gawler M (2002) Strategies for wise use of wetlands: best practices in participatory management, Proceedings of a Workshop held at the 2nd International Conference on Wetlands and Development, November 1998, Dakar, Senegal. IUCN, Gland

Gebreselassie H, Gashaw T, Mehari A (2014) Wetland degradation in Ethiopia: causes, consequences and remedies. Journal of Environment and Earth Science 4, 11. Available via: https://www. iiste.org/Journals/index.php/JEES/article/view/13989/14011. Accessed 28 July 2020

Getahun K, Van Rompaey A, Van Turnhout P, Poesen J (2013) Factors controlling patterns of deforestation in moist evergreen Afromontane forests of Southwest Ethiopia. Forest Ecology and Management 304:171-181

Giweta M, Worku Y (2018) Reversing the degradation of Ethiopian Wetlands: is it unachievable phrase or a call to effective action? International Journal of Environmental Sciences Natural Resources. https://doi.org/10.19080/IJESNR.2018.14.555898

Haji F (2019) A review on: the importance, distribution and threat of Ethiopian wetlands. Journal of Natural Sciences Research 9. Available via: https://iiste.org/Journals/index.php/JNSR/article/ viewFile/47055/48583.. Accessed 28 July 2020

Hillman JV (1993) Ethiopia: compendium of wildlife conservation information. The Wildlife Conservation Society, New York and Ethiopian Wildlife Conservation Organisation, Addis Ababa

Hollis GE (1990) Environmental impacts of development on wetlands in arid and semi-arid lands. Hydrological SciencesJournal 35:411-428

Hughes FMR (1996) Wetlands. In: Adams WM, Goudie SA, Orme AR (eds) The physical geography of Africa. Oxford University Press, Oxford, pp 267-286

IWMI (2014) Wetlands and people. Colombo, Sri Lanka: International Water Management Institute (IWMI). Available via: https://www. iwmi.cgiar.org/Publications/Books/PDF/wetlands-and-people.pdf. Accessed 28 July 2020

Jigar E, Gebru S, Ayalew M (2016) Socio-economic values, threats and legal protection aspects of wetland ecosystem in Afar region, Ethiopia. International Journal of Engineering Development and Research 4. Available via: https://www.ijedr.org/papers/ IJEDR1602039.pdf. Accessed 28 July 2020

Jogo W, Hassan R (2010) Balancing the use of wetlands for economic well-being and ecological security: The case of the Limpopo wetland in southern Africa. Ecological Economics 69:1569-1579

Keenan RJ, Reams GA, Achard F, de Freitas JV, Grainger A (2015) Dynamics of global forest area: Results from the FAO Global Forest Resources Assessment 2015. Forest Ecology and Management 352:9-20

Langan C, Farmer J, Rivington M, Smith JU (2018) Tropical wetland ecosystem service assessments in East Africa: a review of approaches and challenges. Environmental Modelling \& Software 102:260-273

Leauthaud C, Duvail S, Hamerlynck O, Paul JL, Cochet H, Nyunja J, Albergel J, Grünberger O (2013) Floods and livelihoods: The impact of changing water resources on wetland agro-ecological production systems in the Tana River Delta, Kenya. Global EnvironmentalChange 23(1):252-263

MA (Millennium Ecosystem Assessment) (2005) Ecosystems and human well-being: wetlands and water synthesis. World Resources Institute, Washington DC

Maconachie R, Dixon AB, Wood AP (2009) Decentralization and local institutional arrangements for wetland management in Ethiopia and Sierra Leone. Applied Geography 29:269-279

Mafabi P (2005) From conversion to conservation: fifteen years of managing wetlands for people and the environment in Uganda. IUCN, Gland
Maltby E (1986) Waterlogged wealth: why waste the world's wet places? Earthscan, London

Marchand M, Udo HA (1989) The people's role in wetland management. Proceedings of the International Conference in Leiden, The Netherlands, June 5-8th 1989, Centre for Environmental Studies, Leiden University

McCann J (1995) People of the plow: an agricultural history of Ethiopia 1800-1990. University of Wisconsin Press, Wisconsin

McCartney M, Roebelot L, Sellamuttu SS, de Silva S (2010) Wetlands, agriculture and poverty reduction, IWMI Research Report 137. IWMI, Colombo

MoARD (2010a) Ethiopia's Agricultural sector policy and investment framework 2010-2020. Ministry of Agriculture and Rural Development, Addis Ababa. Available via: https:// www.preventionweb.net/files/28796_ethiopiaagriculturepif[30].pdf. Accessed 28 July 2020

MoARD (2010b) National rice research and development strategy of Ethiopia, Ministry of Agriculture and Rural Development, Addis Ababa

MoFED (2003) Rural Development policy and Strategies. Ministry of Finance and Economic Development, Addis Ababa. Available via: http://extwprlegs1.fao.org/docs/pdf/eth144892.pdf. Accessed 28 July 2020

Moges A, Beyene A, Triest L, Kelbessa E (2018) Imbalance of ecosystem services of wetlands and the perception of the local community towards their restoration and management in Jimma highlands, southwestern Ethiopia. Wetlands 38:1081-1095

MoWR (2001) Ethiopian water sector strategy. Ministy of Water Resources, Addis Ababa. Available via: https://www. waterethiopia.org/wp-content/uploads/2014/03/ETHIOPIANWATER-SECTOR-STRATEGY.pdf. Accessed 3 Feb 2021.

Mulatu Kassahun, Hunde Debela, Kissi Endalkachew, (2015) Socioeconomic impacts of wetland cultivation in South-Bench, Southwest Ethiopia. African Journal of Agricultural Research 10 (8):840-848

Mulugeta S (2004) Socio-economic determinants of wetland cultivation in Kemise, Illubabor Zone, southwestern Ethiopia. Eastern Africa Social Science Research Review 20:93-114

Mundy P (2009) Planting trees to eat fish: field experiences in wetlands and poverty reduction. Wetlands International, Wageningen

Munishi A, Jewitt G (2019) Degradation of Kilombero Valley Ramsar wetlands in Tanzania. Physics and Chemistry of the Earth 112:216 227

Olsson P, Folke C, Berkes F (2004) Adaptive co-management for building resilience in social-ecological systems. Environmental Management 34:75-90

Ostrom E (1990) Governing the commons: the evolution of institutions for collective action. Cambridge University Press, Cambridge

Ostrom E (2009) A general framework for analyzing the sustainability of socio-ecological systems. Science 325:419-422

Oviedo G, Kenza Ali M (2018) The relationship of indigenous peoples and local communities with wetlands. Ramsar Convention Secretariat, Gland. Available via: https:/www.ramsar.org/sites/ default/files/documents/library/indigenous_peoples_local_ communities_wetlands_e.pdf. Accessed 28 July 2020

Pettinottia L, de Ayalaa A, Ojea A (2018) Benefits from water related ecosystem services in Africa and climate change. Ecological Economics 149:294-305

PHE (2012) Integrated practical success stories and challenges from the field: Ethio-wetlands and Natural Resources Association. PHE Consortium, Addis Ababa. Available via: https://phe-ethiopia.org/ pdf/Ethio wetlands spotlight.pdf. Accessed 28 July 2020

Pretty J, Ward H (2001) Social capital and the environment. World Development 29:209-227 
Quirin C, Dixon AB (2012) Food security, politics and perceptions of wildlife damage in western Ethiopia'. International Journal of Pest Management 58:101-114

Ramsar (2018) Resolution XIII.15: Cultural values and practices of indigenous peoples and local communities and their contribution to climate-change mitigation and adaptation in wetlands. Available via: https://www.ramsar.org/document/resolution-xiii15-culturalvalues-and-practices-of-indigenous-peoples-and-localcommunities. Accessed 28 July 2020

Roberts N (1988) Dambos in development: management of a fragile ecological resource. Journal of Biogeography 15:141-148

Rodenburg J, Zwart SJ, Kiepe P, Narteh LT, Dogbe W, Wopereis MCS (2014) Sustainable rice production in African inland valleys: Seizing regional potentials through local approaches. Agricultural Systems 123:1-11

Roggeri H (1998) Tropical freshwater wetlands: a guide to current knowledge and sustainable management. Kluwer Academic Publishers, Dordrecht

Sakane N, Becker M, Langensiepen M, van Wijk MT (2012) Typology of smallholder production systems in small East-African wetlands. Wetlands 33:101-116

Schmidt E, Tadesse F (2019) The impact of sustainable land management on household crop production in the Blue Nile Basin, Ethiopia. Land Degradation and Development 30:777-787

Schuyt KD (2005) Economic consequences of wetland degradation for local populations in Africa. Ecological Economics 53:177-190

Scoones I (1991) Wetlands in drylands: key resources for agricultural and pastoral development in Africa. Ambio 20:366-371

Silvius MJ, Oneka M, Verhagen A (2000) Wetlands: Lifeline for people at the edge. Physics and Chemistry of the Earth, Part B: Hydrology, Oceans and Atmosphere 25:645-652

Tafa D (2018) Preliminary survey of wetland in Ethiopia, threats, extent of degradation, and future perspective: a review paper. Journal of Ecology of Health Environment 6:93-98

Takele A (2010) Analysis of rice profitability and marketing chain: the case of Fogera Woreda, South Gondar Zone, Amhara National Regional State, Ethiopia: ILRI-IPMS. MSc thesis (Agricultural Economics), Haramaya University, Haramaya

Tanko AI (2013) Agriculture, livelihoods and fadama restoration in northern Nigeria. In: Wood AP, Dixon B, McCartney M (eds) Wetland management and sustainable livelihoods in Africa. Earthscan, London, pp 205-228

Tarhule A, Woo M (1997) Characteristics and use of shallow wells in a stream fadama: a case study in northern Nigeria. Applied Geography 17:29-42

Tesfaye G, Wolff M (2014) The state of inland fisheries in Ethiopia: a synopsis with updated estimates of potential yield. Ecohydrology and Hydrobiology 14:200-219

Trapnell CG, Clothier JN (1937) The soils, vegetation and agriculture systems of North-Western Rhodesia. Government of Northern Rhodesia, Lusaka
Tulu FD, Desta MA (2015) Human development and wetland conservation policy. International Journal of Environmental Sciences 4:126138

Turner B (1986) The importance of dambos in African agriculture. Land Use Policy 3:343-347

Virapongse A, Brooks S, Metcalf EC, Zedalis M, Gosz J, Kliskey A, Alessa L (2016) A social-ecological systems approach for environmental management. Journal of Environmental Management 178: 83-91

Wetlands International (2005) The wetlands and poverty reduction project: linking wetland conservation and poverty alleviation. Wetlands International, Wageningen

Whitlow JR (1983) Vlei cultivation in Zimbabwe: reflections on the past. Zimbabwe Agriculture Journal 80:123-135

Wondie A (2018) Ecological conditions and ecosystem services of wetlands in the Lake Tana Area, Ethiopia. Ecohydrology \& Hydrobiology 18:231-244

Wood AP, Dixon AB (2000) Sustainable wetland management in Illubabor Zone: Research report summaries. Unpublished Report, The University of Huddersfield. Available via: https://www. wetlandaction.org/wp-content/uploads/EWRP-ObjectiveSummaries.pdf. Accessed 28 July 2020

Wood AP, Thawe P (2013) Catchments and wetlands: a functional landscape approach to sustainable use of seasonal wetlands in central Malawi. In: Wood AP, Dixon B, McCartney M (eds) Wetland management and sustainable livelihoods in Africa. Earthscan, London, pp 63-84

Wood AP, van Halsema G (2008) Scoping agriculture-wetland interactions: towards a sustainable multiple response strategy (Water Resources Report 33). FAO, Rome

Wood AP, Dixon AB, McCartney M (2013) (Eds) Wetland management and sustainable livelihoods in Africa. Earthscan, London

Wood AP, Sutcliffe P, Dixon AB (2016) Wetlands of the Baro-Akobo River system in Ethiopia. In: Finlayson CM, Milton GR, Prentice RC, Davidson NC (eds) The Wetland Book. Springer, Dordrecht, pp 1261-1267

Woodhouse P, Bernstein H, Hulme D (2000) African enclosures? The social dynamics of wetlands in drylands. James Currey, Oxford

World Bank (2020) World development indicators database. Available via: https://data.worldbank.org/. Accessed 28 July 2020

Yilma G (2019) Socio-economic contribution of rift value aquatic and wetlands to the local community and the national economy: the case of Lake Hawassa and associated wetlands, in the southern part of Ethiopia. International Journal of Environmental Sciences Natural Resources 22. https://doi.org/10.19080/JJESNR.2019.22.556096

Young NE, Evangelista PH, Mengistu T, Leisz S (2020) Twenty-three years of forest cover change in protected areas under different governance strategies: A case study from Ethiopia's southern highlands. Land Use Policy 91:104426

Publisher's Note Springer Nature remains neutral with regard to jurisdictional claims in published maps and institutional affiliations. 